\title{
O entrelugar do cânone na pós-modernidade: o cânone e os estudos culturais
}

\section{Carmem Cristiane Borges Losano}

Mestre em Teoria Literária e Crítica da Cultura

(UFSJ); doutoranda em Literatura Comparada:

Poéticas da Modernidade (UFMG); professora de

Ensino Superior (UEMG), em Barbacena (MG).

Resumo: Breve descrição dos aportes teóricos da Literatura Comparada, seguida de uma abordagem do cânone, com base na relativização, na modernidade, de sua pertença à tradição literária, para cuja análise são requeridas as teorias de Walter Benjamin, que, de certa forma, revolucionou a noção e o significado do cânone no âmbito das artes. A partir de então, verifica-se a condição de entrelugar do cânone, na pósmodernidade, ante as análises de teóricos adeptos aos Estudos Culturais, como nova tendência de posicionamento da crítica artístico-cultural.

Palavras-chave: cânone; tradição; pósmodernidade
Abstract: This paper presents a brief description of the theoretical framework of the Comparative Literature, followed by an approach of the literary canon, from their membership in the literary tradition. The canonical tradition is questioned, in Modernity, with the theories of Walter Benjamin who, in a sense, revolutionized the concept and meaning of the canon within the arts. Since then, we verify the condition of in-between place of the canon, in Postmodernity, compared to the theoretical analysis of adherents of Cultural Studies as a new trend of positioning of artistic and cultural criticism.

Key words: canon; tradition; post-modernity 



\section{Introdução}

Não é por acaso que Walter Benjamin elegeu Paris como a capital do século XIX, o período da História que se afirmou como o século da Modernidade ${ }^{l}$ - a fase do progresso do espaço urbano e da consequente transformação dos seres humanos em fantoches do sistema capitalista. A convicção de Walter Benjamin, quando "denunciava" a Modernidade evidente em Paris, de certa forma previa o que viria em seguida: o mundo contemporâneo da automatização e do imediatismo proporcionado pela técnica ${ }^{2}$. Tantas transformações provocaram consideráveis alterações na sociedade, visto que os vários campos do conhecimento não ficariam imunes. Era, pois, de esperar que os estudos literários também sofressem alterações. Uma dessas alterações diz respeito ao lugar do cânone. Até meados do século $\mathrm{XX}$, as obras de arte realizadas por homens brancos europeus falecidos poderiam ter a chance de ingressar na lista de obras canônicas, ou seja, as obras que seriam universalizadas, imortalizadas. Considerandose tais critérios, fica claro que muitas obras de arte permaneceram fora dessa lista, no decorrer da história da literatura.

E hoje, no século XXI, os teóricos dos Estudos Culturais dedicam suas pesquisas à valorização das obras consideradas marginais, através da valorização da identidade cultural dessas obras - noção traduzida no sentimento de um indivíduo para com o seu grupo cultural, na medida em que é influenciado pelo grupo. É através da identidade cultural que se desenvolve o sentimento de pertencimento a uma comunidade, sociedade ou nação. Daí o desmembramento do conceito em outros, como identidade nacional, ou seja, o vínculo pessoal do indivíduo com sua nação, através da cultura. Entretanto, perante uma longa trajetória de desvalorização das obras consideradas marginais (realizadas por não brancos, por não europeus, por mulheres, gays e outras "minorias"), como poderíamos propor uma alteração dessa perspectiva? A partir das teorias de Walter Benjamin, particularmente
1 Modernidade é um termo polissêmico, portanto, complexo. Empregamos tal termo no sentido utilizado por Walter Benjamin, ao realizar suas análises e seus escritos sobre o poeta francês Charles Baudelaire.

2 É preciso ter em mente que Benjamin não tinha uma visão tão negativa da técnica quanto Adorno. 
a noção de Erfahrung (experiência), que pode ser compreendida a partir da transmissão de conhecimentos e vivências sociais, mantidos nas tradições e repassados por elas. A tradição se constitui, pois, a partir de celebrações, costumes, lendas, narrativas e rituais que são vivenciados e transmitidos, de geração a geração, através das releituras, ou mesmo reconstruções das experiências.

Assim sendo, podemos afirmar que o refazer - as releituras - pode se aplicar ao que Georg Otte considera como "reconstrução da experiência": "A ininterrupta reconstrução da experiência pelas gerações sucessivas evita que ela caia em des-uso [grifo do autor] e que ela passe a fazer parte de um cânone autoritário, tornandose um corpo estranho para uma determinada atualidade" (OTTE, 1999, p.14).

No caso da narrativa - mais especificamente a literatura -, podemos nos apropriar da noção de reconstrução da experiência para compreender o valor das reconstruções. Considerando que a cada refazer a experiência é renovada, temos que a reconstrução da experiência, além de funcionar como estratégia de anticanonização, ainda mantém vivas as obras nas quais permanecem os traços de identidade cultural/nacional de cada sociedade. Dessa forma, tais obras adquirem e mantêm seu valor cultural, segundo os critérios de valoração analisados pelos Estudos Culturais. Essa reconstrução proposta passa, por assim dizer, pela Desconstrução, "apropriada" pelos Estudos Culturais, que reavaliam as manifestações artísticas e/ou culturais, independentemente dos velhos critérios de consagração das obras.

A "Escola do Ressentimento" - como Harold Bloom ironicamente denomina os teóricos culturalistas - passa a rever e a reconstruir os conceitos acerca das obras ditas marginais. Toda essa renovação teórica faz estremecer, por assim dizer, o lugar das obras canônicas, deslocando o canônico para um entrelugar, para uma condição de desconforto em relação à valorização das obras realizadas pelas minorias, não canônicas. 
Tendo em vista que a academia é o lugar onde se discutem as questões relevantes para as ciências - e, no presente caso, as ciências humanas, sociais e as artes -, entendemos que tal discussão contribui para o meio acadêmico, pois nos permite uma revisão desse histórico da crítica de arte, mais precisamente da arte marginal, de forma a redefinir seu valor na atualidade. A história da arte pode nos revelar muito acerca da linha divisória entre o canônico e o marginal. É nessa história que se concentram os elogios aos grandes feitos, aos grandes nomes, dos grandes artistas; o que fica escondido, ou "marginalizado", ou seja, a arte menor, não é objeto de elogios mas, ainda assim, faz parte dessa mesma evolução histórica.

\section{Comparativismo literário: aportes teóricos}

$\mathrm{O}$ estudo de literatura comparada envolve a ultrapassagem das fronteiras; o fato leva-nos a considerála como disciplina de intersecção, de troca de influências entre diferentes literaturas e entre diferentes culturas. Nesse sentido, precisamos dissecar o conceito em subconceitos: literatura nacional, literatura mundial e literatura geral. O primeiro se confunde com o próprio conceito de literatura comparada, pelo fato de ela poder lidar com autores de diferentes nacionalidades. Já no que tange à literatura mundial, há nesse conceito um sentido de permanência, de sobrevivência à passagem do tempo, normalmente referindo-se aos clássicos da literatura mundial, que exerceram e ainda exercem influência sobre os novos escritores. Por último, o conceito de literatura geral, que lida com tendências, problemas e teorias passíveis de interesse por parte da literatura como um todo, independentemente de fronteiras.

Ao tratar das literaturas de diferentes países, a literatura comparada, na qualidade de disciplina, parece abordar simplesmente as influências entre autores. Nesse sentido, falar em influência é tocar em um ponto frágil dos estudos comparativos, pois o termo pode ser visto sob um ângulo pejorativo, como se um autor estivesse produzindo 
por paráfrase, ou mesmo por cópia de outro. Sabemos que a visão sobre a influência deve ser outra: a influência tem que ser vista com critérios e sem preconceitos, a fim de que se possam realizar estudos comparativos confiáveis. Sobre a abordagem comparativa, Victor Zhirmunsky afirma que a atenção centrada nas "influências literárias" ignora fatos relevantes, como a personalidade criativa do autor e a conexão da obra com a vida social que ela reflete, sua origem nacional e histórica e as adaptações ao tempo, lugar e individualidade, aos quais tais "empréstimos" necessariamente se sujeitam. Sobre a questão da influência, Leyla Perrone-Moisés afirma que

Estudando relações entre diferentes literaturas nacionais, autores e obras, a literatura comparada não só admite, mas comprova que a literatura se produz num constante diálogo de textos, por retomadas, empréstimos etrocas. A literatura nasce da literatura: cada obra nova é uma continuação, por consentimento ou contestação, das obras anteriores, dos gêneros e temas já existentes. Escrever é, pois, dialogar com a literatura anterior e com a contemporânea (PERRONE-MOISÉS, 1990, p.94).

Podemos verificar que os indícios de absorção de influências, percebidos durante a análise da obra de um autor, são parte integrante da obra, são indícios de que o autor está em interação com a produção artística que floresce no meio onde está inserido, e até com a produção que floresce em outros países. Tal interação denota o interesse do autor pela produção de outros autores, o que vem a qualificar positivamente o autor em questão, como também sua obra.

No que tange aos estudos referentes às influências, Perrone-Moisés retoma teóricos que trabalharam tal questão e que, de certa forma, colaboraram para a desmistificação do aspecto negativo da influência. O primeiro teórico do qual a autora trata é Mikhail Bakhtin (1929), que, tendo estudado a obra de Dostoievski, verificou 
a polifonia existente na obra - e entre a obra e outras obras - , de forma a desenvolver a teoria do dialogismo. Sua teoria se baseia no diálogo entre sujeitos do discurso, o que no comparativismo se traduz, basicamente, como o diálogo entre obras literárias.

Em continuidade a Bakhtin, Julia Kristeva desenvolveu a chamada teoria da intertextualidade, a qual continua em desenvolvimento por estudiosos da linguagem. A pesquisadora, tendo chegado a considerar o texto como um mosaico de citações, trabalhou com a noção de fontes, tendo afirmado que "as fontes deixam de interessar por elas mesmas; elas só interessam para que se possa verificar como elas foram usadas, transformadas" (PERRONE-MOISÉS, 1990, p. 94). Afirmou, ainda, que as influências são produtos de um confronto produtivo com o Outro, ou seja, são frutos de leituras e interpretações que ocorrem em vários sentidos e direções e que geram uma nova rede de autores e obras, em um processo contínuo de produção de novos "mosaicos".

Percebemos que tanto Bakhtin quanto Kristeva formularam e desenvolveram teorias bastante úteis para uma nova concepção da noção de influência ${ }^{3}$; suas teorias relativizaram as noções de "novo" e de "original", de forma a provocar uma nova atitude por parte dos comparatistas. Mas ainda havia uma questão incômoda na análise das obras - a questão da tradição. Os teóricos que se debruçaram sobre essa questão foram Tiniánov, Jorge Luis Borges e T. S. Eliot (este último não citado por Perrone-Moisés, mas por Carvalhal).

O nome de Tiniánov é mencionado por PerroneMoisés como um dos precursores na revisão do conceito de tradição. O formalista russo trata da evolução literária, referindo-se à tradição como um conceito falso, que deve ser visto sob outro ponto de vista - o que denota sua fuga ao formalismo ortodoxo. Nesse sentido, Tiniánov define que a obra se relaciona com um conjunto de séries culturais, como também com as outras obras literárias, anteriores e contemporâneas. Ou seja, sua teoria estimula uma nova forma de análise,
3 Sobre a questão da influência, tanto Carvalhal quanto Perrone-Moisés mencionam a obra denominada The anxiety of influence, de Harold Bloom (1973). 
redimensionando a concepção de tradição. Além disso, Tiniánov ainda retoma a noção de "influência", criando a de "convergência", ou seja, "coincidências de temas e de soluções formais que nada têm a ver com as influências, mas com a existência de certas condições literárias em determinado momento histórico" (PERRONE-MOISÉS, 1990, p. 95).

Perrone-Moisés menciona também o nome de Jorge Luis Borges, quando trata da noção de tradição. Em termos gerais, Borges redimensiona a noção, afirmando que se trata de uma questão de leitura (recepção); e, visto que a leitura muda constantemente, a tradição está constantemente sendo revista. Em outras palavras, ele observa como uma obra forte nos obriga a uma releitura de todo um passado literário. Podemos verificar que a tradição, antes vista como um conceito estático, firme como as paredes dos museus, torna-se flexível e mutante, a partir da teoria de Borges. Carvalhal, ao mencionar o escritor, lembra-nos de que ele conseguiu mais que isso. Ela afirma que, no que tange à questão da influência, Borges desloca o ângulo de observação, afirmando que, se há alguma dívida (de influência), ela é do texto anterior para com aquele que o descobriu - e não o contrário, como se pensava. Daí seu famoso texto "Pierre Menard, autor do Quixote" representar uma ruptura com as noções de originalidade e de autoria.

Mais escritor que teórico, Oswald de Andrade (1928) é lembrado por Perrone-Moisés em função da Antropofagia cultural, proposta como uma devoração crítica do Outro, uma ideia inspirada nos costumes dos índios canibais, os quais acreditavam que, ao devorar um outro humano, seriam detentores das qualidades da vítima. Nesse sentido, existe aqui uma analogia com a teoria da intertextualidade. No que se refere à tradição, a autora afirma que a Antropofagia, na qualidade de um projeto filosófico e cultural, pretende nossa liberação de dívidas para com o passado europeu (o que para nós representaria um rompimento com a tradição não nacional, uma busca de nossa própria identidade). 
Ainda sobre a tradição, devemos mencionar o ensaio chamado "A tradição e o talento individual", de T. S. Eliot. O crítico foi lembrado por Carvalhal porque sustenta, nesse ensaio, noções básicas para uma renovação dos estudos comparados. No ensaio, Eliot afirma que aquilo que o leitor busca de diferencial no poeta acaba por ser o elemento que une este poeta a seus antecessores; dessa forma, conclui que nenhum poeta tem valor isolado, porque estará sempre relacionado à produção poética anterior. Sobre as teorias relativas às noções da influência e da tradição, Perrone-Moisés conclui:

Essas propostas teóricas do século $\mathrm{XX}$ nos convidam a rever os pressupostos e os objetivos da literatura comparada. Comparar é sempre ver semelhanças e diferenças. O que se pode propor, agora, como transformação dos objetivos da literatura comparada, é uma mudança na ênfase que se pode dar ou às semelhanças ou às diferenças (PERRONE-MOISÉS, 1990, p. 96).

Ao tratarmos da "transformação dos objetivos da literatura comparada", Carvalhal (1986) traz à tona a questão da literatura comparada em relação à dependência cultural, propondo uma solução - um novo discurso crítico que esqueça e negligencie a caça às fontes e influências e estabeleça como único valor a diferença. A diferença, nesse caso, seria um fator de afirmação da identidade nacional, abrindo caminhos para a inserção do nacional no universal. Nesse sentido, a autora retoma o projeto oswaldiano da Antropofagia, para inverter a velha direção colonizador/colonizado: passar de devorado a devorador, selecionar do alheio somente o que interessa. Assim, passamos por uma superação constante de complexos, com a finalidade de tentar concluir o nosso processo de "descolonização literária". Essa questão é abordada por Silviano Santiago, em sua obra Uma literatura nos trópicos, a qual contém ensaios relativos à questão da dependência cultural. Santiago, da mesma forma que Perrone-Moisés, propõe o estabelecimento do 
critério da observação da diferença como nova posição dos estudos literários.

Tocando especificamente no conteúdo da obra do escritor latino-americano, que sofre - em todos os sentidos - a influência da expressão artística da metrópole, Santiago aborda a questão do procedimento da crítica ante essa obra, enfatizando a necessidade do escritor de conhecer e de trabalhar sobre o texto-fonte, de forma a combatê-lo melhor. Dessa forma, o trabalho da crítica seria o de analisar, primeiramente, o uso que o escritor fez do texto-fonte; e, em segundo plano, a "descrição da técnica que o mesmo escritor cria em seu movimento de agressão contra o modelo original, fazendo ceder as fundações que o propunham como objeto único e de reprodução impossível" (SANTIAGO, 2000, p. 21).

Para melhor exemplificar a teoria apresentada no ensaio, Santiago retoma o conto (já mencionado neste trabalho) "Pierre Menard, autor de Quixote", de Borges. Menard representa, no caso, a metáfora do escritor latinoamericano, que produz suas obras a partir do já-escrito, em um jogo de combate cultural contínuo. E seria, pois, justamente entre o que lê e o que produz, entre o que sofre e o que expressa, o lugar onde acontece, nas palavras de Santiago, o ritual antropofágico da literatura latino-americana. Portanto, após essa rápida passagem pelas teorias que circulam no campo da literatura comparada, e ainda, pelas críticas a posições centradas em tradicionalismos, podemos nos encaminhar para um estudo comparativo entre as leis da tradição canônica e as tendências desconstrutoras que se insurgem na pósmodernidade.

\section{O sagrado lugar do cânone}

Para compreendermos a sacralidade do lugar do cânone, é preciso compreender como se constituiu, no passado, a formação desse lugar. O termo é originário do grego (kanón), tendo passado pelo latim (canon), com o significado de regra. No decorrer do tempo, o termo passou a compreender o conjunto de textos considerados 
como modelos de perfeição. Segundo a doutrina católica, canonizados são os santos reconhecidos pela autoridade maior do catolicismo, o papa. No caso da literatura, canonizados são os autores (e suas respectivas obras) que são considerados os mestres da tradição.

Segundo Leyla Perrone-Moysés (1998), a palavra cânone, na qualidade de representação de uma relação de escritores consagrados, ocorreu, pela primeira vez, no século IV e, a partir de então, foi adotada por escritores e críticos, em diferentes países da Europa, particularmente Itália e França, onde "o conceito francês de cânone clássico só se abala no século XVIII, com a abertura para os autores ingleses e alemães, e com a adoção do conceito de Weltliteratur, de Goethe" (PERRONE-MOISÉS, 1998, p. 62).

A autora afirma, ainda, que foi a partir do século XVIII que o juízo estético deixou de ser considerado universal, de forma que os autores "clássicos" se tornaram "exemplos de uma regra universal impossível de enunciar" (KANT apud PERRONE-MOISÉS, 1998, p. 63). Já no século $X X$, os escritores valorizados passaram a ser nomeados pelo viés do gosto da crítica, o que se justificava pela prática: "suas escolhas não são ditadas por nenhuma autoridade institucional, mas pelo gosto pessoal, justificado por argumentos estéticos e pela própria prática; é o que a Modernidade herdou do romantismo teóricocrítico" (PERRONE-MOISÉS, 1998, p. 63).

Dessa forma, depreendemos que, da Antiguidade à Modernidade, a preocupação em estabelecer o lugar do cânone sempre foi uma constante. Não se poderia conceber uma literatura de qualidade sem que se pudesse fazer referência a um modelo, um padrão de produção de obras literárias que servisse como guia, seja para os estudantes, seja para a crítica profissional.

Para o iniciante cultural, atormentado pela total falta de orientação, saber o que há de sagrado pode conferir uma certa segurança psicológica. Embora essa submissão voluntária ao cânone oficial possa ser questionada, ela se justifica, ao mesmo tempo, 
enquanto etapa necessária rumo à emancipação do indivíduo, pois não é o desconhecimento do cânone que garante a independência dele (OTTE, 1999, p.09).

Portanto, seja o cânone considerado como uma lista sagrada de obras literárias, ou mesmo como uma garantia psicológica para iniciantes culturais, o referencial canônico da literatura universal não se perde no tempo, nem no espaço. Sua autoridade existe e é mantida pela tradição cultural universal. Segundo Harold Bloom (2001), crítico norte-americano - e ferrenho defensor da manutenção do lugar do cânone - , "o Cânone é de fato um metro de vitalidade, uma medida que tenta mapear o imensurado. A antiga metáfora da imortalidade do escritor é relevante aqui, e renova o poder do Cânone para nós [...]. Sem o Cânone, deixamos de pensar" (BLOOM, 2001, p. 46-47).

Ao tratarmos da questão do cânone como uma representação da tradição literária, reportamo-nos mais uma vez ao ensaio de T. S. Eliot (1989), “Tradição e talento individual", no qual o autor demonstra como o apoio na tradição pode formar um grande poeta; demonstra como o conhecimento da tradição se harmoniza com o talento individual para essa formação. Nesse sentido, Eliot deixa claro que, por mais que o leitor esteja em busca do traço individual de cada poeta, o seu diferencial em relação aos outros, a influência dos seus antecessores deveria se fazer conhecer, no sentido de tornar possível averiguar, em suas obras, o conhecimento (bem como a influência) da tradição literária.

Ou seja, o crítico deixa claro que o apego à tradição - e, portanto, ao cânone literário - seria um fator de valorização do poeta. Contudo, esclarece que esse apego não deveria se constituir sobre uma mera aderência à geração literária imediatamente anterior, mas sim a um sentido histórico de tradição, o que compreende uma abordagem temporal bem mais ampla: 
[...] o sentido histórico implica a percepção, não apenas da caducidade do passado, mas de sua presença; o sentido histórico leva um homem a escrever não somente com a própria geração a que pertence em seus ossos, mas com um sentimento de que toda a literatura europeia desde Homero e, nela incluída, toda a literatura de seu próprio país têm uma existência simultânea e constituem uma ordem simultânea [...] (ELIOT, 1989:39).

Nesse trecho, podemos verificar a necessidade de o poeta se colocar em uma condição temporal unificada, em que presente e passado não se formariam numa linearidade, mas num mesmo plano, onde a simultaneidade da produção poética seria uma referência. Eliot ainda demonstra, aqui, uma tendência a pensar na literatura nacional, ou seja, na identidade nacional do poeta, que se formaria no diálogo entre suas obras e as de seus antecessores, de mesma nacionalidade. Eliot esclarece: "esse sentimento histórico, que é o sentido tanto do atemporal quanto do temporal e do atemporal e do temporal reunidos, é que torna um escritor tradicional" (ELIOT, 1989:39). Segundo o crítico, os ajustes e reajustes entre as obras que compõem a tradição e as obras novas poderiam se fazer a partir de uma leve alteração da ordem existente entre elas, de forma que tais reajustes possam abrigar, harmonicamente, o antigo e o novo. Seria a tradição aceitando a novidade, desde que seja de forma ajustável à sua ordem, já consolidada no tempo e no espaço.

Nessa busca de conhecimento do passado, bem como nessa incorporação do passado pelo presente, em um plano atemporal, ocorre uma contínua entrega do poeta, num processo de despersonalização, em prol da tradição. Suas emoções pessoais não devem se integrar à sua produção poética; ao contrário, na produção poética a emoção deve ser algo bem mais complexo, resultado de um trabalho poético que permita a expressão de sentimentos que não se confundam com as emoções, tais como são reconhecidas e vivenciadas. A partir do 
exposto pelo crítico, o poeta poderia ser considerado como um retransmissor da tradição, que conseguisse aliar esse conhecimento da produção literária anterior a um talento individual - o qual pudesse ser notado através da capacidade de trabalhar as emoções humanas até o ponto de transformá-las em arte.

Visto que a tradição requer a leitura e o conhecimento das obras dos grandes mestres do passado, podemos compreender a dedicação de Ítalo Calvino à defesa dos clássicos. Calvino, na qualidade de escritorcrítico moderno, valorizava as múltiplas dimensões de significados que uma obra poderia conter: "o que conta para nós na obra literária é a possibilidade de continuar a desfolhá-la como uma alcachofra infinita, descobrindo dimensões de leitura sempre novas" (CALVINO apud PERRONE-MOISÉS, 2000, p. 285). Dentre as qualidades de uma obra clássica, a oferta de várias possibilidades de significados é relevante; talvez porque, com o decorrer do tempo e a evolução da cultura, a obra com tal característica seja continuamente lida, compreendida e vivificada através dos leitores de cada época.

\section{A tradição na Modernidade: relativizações do cânone}

Relativizar valores já consagrados, em qualquer cultura, não constitui uma tarefa das mais fáceis. Como pode ser notado neste trabalho, a tradição é um conjunto de valores que se consolidam no tempo e no espaço, de forma que tendências contrárias nem sempre são bem recebidas. Uma das novidades do mundo moderno que alterou valores tradicionais foi a reprodutibilidade técnica das obras de arte; não é possível abordar, por exemplo, a recepção da arte no século XX sem passar pelo exame da técnica. Da pintura e escultura à fotografia e ao cinema, a produção de arte, bem como sua recepção, passaram por profundas alterações.

Walter Benjamin (1994), em seu ensaio intitulado "A obra de arte na era de sua reprodutibilidade técnica", tratou dessa questão, tendo perpassado os momentos 
da história da humanidade em que a arte passou a ser reproduzida; Benjamin focou sua abordagem no momento em que a reprodução, ao passar pela técnica, passou a ser instrumento de divulgação, em massa, da obra de arte o que favoreceu o acesso às obras, por assim dizer. Por outro lado, a técnica serviu (e serve, até os dias atuais) ao desenvolvimento e à consolidação da comunicação de massa e, na mesma esteira, do sistema capitalista.

Ao dedicarmos nossas análises à questão do cânone, e de seu lugar na sociedade, poderíamos nos questionar: como a reprodutibilidade técnica poderia interferir nessa questão? Ora, o cânone é uma expressão de um padrão cultural que se mantém valorizado através das gerações, servindo de modelo para a produção e referência para a recepção da arte, na sociedade. Desse modo, a obra canônica contém um valor de culto, assim definido por Benjamin:

O valor de culto, como tal, quase obriga a manter secretas as obras de arte: certas estátuas divinas somente são acessíveis ao sumo sacerdote, na cela, certas madonas permanecem cobertas quase $\mathrm{o}$ ano inteiro, certas esculturas em catedrais da Idade Média são invisíveis, do solo, para o observador (BENJAMIN, 1994, p. 173).

Da mesma forma, o acesso às obras canônicas deveria se restringir apenas a uma elite letrada; mesmo que a obra pudesse ser acessível, sua compreensão não o seria. Porém, com o decorrer do tempo, algumas modalidades de obras de arte passaram por adaptações, desenvolvendo sua capacidade de exposição. Vejamos a diferença entre a exposição de um busto (que pode ser deslocado facilmente) e a de uma estátua; entre a exposição de um quadro e a de um afresco; entre a exposição de uma fotografia e de um quadro; entre a exposição de uma obra arquitetônica in loco e de sua imagem, através de um filme. Em todos os casos, o valor de culto cede ao valor de exposição.

Nesse sentido, reconhecemos o valor de exposição das obras como uma nova possibilidade, advinda das 
mudanças na produção - o que muda, também, a recepção da arte: a capacidade de exposição de uma obra de arte cresceu em tal escala, com os métodos de sua reprodutibilidade técnica, que o valor de culto cedeu lugar a um valor de exposição da obra, como arte para ser vista e divulgada. Portanto, célebres obras de arte, que deveriam ser cultuadas, perdem seu valor de culto, para ser valorizadas pelo recurso à exposição. Em outros termos, perdem sua "aura", sendo o aqui e agora da obra de arte substituído pela reprodução.

No ensaio benjaminiano, não percebemos referências diretas à obra literária; porém, entendemos que, no caso da obra literária canônica, é possível relacionar a perda da aura a vários mecanismos de reprodução, tais como adaptações, traduções, encenações, filmagens. O cânone pode ser lido e relido, visto e revisto sob diferentes releituras, que subvertem a tradição e, assim, dessacralizam a obra, tornando-a mais acessível à sociedade. Nos dias atuais, a peça shakespeariana Romeu e Julieta pode ser encontrada na literatura infantil, nas versões para adolescentes, em traduções diversas, nos palcos do mundo inteiro e até no cinema, sob os mais diversos tratamentos. Após a reprodutibilidade técnica, o cânone do século XVII está ao alcance do receptor comum, da sociedade em geral.

Georg Otte (1999) nos auxilia na compreensão de uma relativização do lugar do cânone na literatura tomando como base outro ensaio benjaminiano, "O narrador: considerações sobre a obra de Nikolai Leskov". Nesse ensaio, Benjamin se refere mais detidamente à narrativa, com a nítida indignação com o fato de a narrativa oral ter se perdido no tempo, em função da escrita, mais precisamente, do romance. Otte comenta o tratamento dado por Benjamin à preservação da narrativa oral:

Se, no ensaio sobre a aura, o "interesse em conservar" ainda era algo suspeito, pois levava à formação de uma aura distanciadora, Benjamin defende a preservação de uma espécie de tesouro de narrativas no caso do Narrador. $\mathrm{O}$ “interesse em 
conservar o que foi narrado" partiria de um cânone sem culto e sem aura, pois falta à narrativa oral uma característica que parece ser indispensável para a formação da aura: sua concretização como obra materialmente fixada. A narrativa, por ser oral, tem que circular entre os membros de uma determinada comunidade; parando de circular, ela para de existir. [...] É portanto a própria oralidade que obriga narradores e ouvintes, que, por sua vez, se transformam em narradores, a se juntar para participar da "experiência" coletiva (OTTE, 1999, p. 13-14).

A partir da citação, entendemos como a narrativa oral "escapou" do processo de canonização: além de não possuir materialidade física, era transmitida sob a condição de permitir constantes releituras; cada narrador que se apropriava de uma determinada narrativa para transmitila dava-lhe um contorno próprio, sua marca, seus vestígios. Visto que o vestígio e a aura ${ }^{4}$ são considerados por Benjamin como conceitos opostos, então podemos concluir que a narrativa oral, por conter incontáveis vestígios de narradores, não poderia, de forma alguma, desenvolver uma aura — nem poderia, portanto, tornarse canônica.

O uso artesanal faz com que a narrativa, como a argila do oleiro, seja constantemente modelada e remodelada conforme as particularidades de cada presente. A ininterrupta reconstrução da experiência pelas gerações sucessivas evita que ela caia em des-uso e que ela passe a fazer parte de um cânone autoritário, tornando-se um corpo estranho para uma determinada atualidade (OTTE, 1999, p.14).

Sendo assim, é possível compreender como a reconstrução da experiência, própria da narrativa oral, pode ser considerada como um mecanismo de manutenção da obra sob o poder dos produtores e receptores, de forma a evitar seu isolamento e, portanto, sua canonização.
${ }^{4}$ Considera-se vestígio um traço de identidade que cada artista deixa na sua obra, tal como as marcas das mãos do oleiro permanecem no vaso; e aura a característica intrínseca à obra de arte original, que impõe ao receptor uma espécie de culto, ou veneração. 
Dado o exposto, cogitamos a possibilidade de estender tal reconstrução a outras formas de manifestação da arte e da cultura, com a releitura e a reinterpretação das obras canônicas, trazendo-as para o uso da coletividade.

Antes mesmo da técnica, as adaptações de narrativas, pelo mero ato de narrar, já evitavam a formação de uma crosta canonizante. Vejamos o caso das peças teatrais: cada montagem também é uma releitura; vejamos as adaptações: cada adaptação de uma obra também é uma releitura; no caso das traduções, essas obras são releituras. Se observarmos que toda releitura contém vestígios de um novo produtor - e de novos leitores, na recepção - , então as releituras são relativizações constantes do cânone constituído. Nesse sentido, a reprodutibilidade técnica não seria só um mecanismo de perda da aura; mais que isso, implicaria a evolução das releituras, de todos esses mecanismos de dessacralização do lugar do cânone.

\section{O entrelugar do cânone na pós-modernidade}

No contexto cultural contemporâneo, em que a obra marginal e o cânone se encontram sob a égide da teoria da Desconstrução e em que as múltiplas identidades culturais se entrelaçam em um contexto maior, cabe-nos entender que o valor cultural das manifestações originadas de diferentes sociedades não se concentra mais nos velhos critérios de canonização das obras, mas também na valorização das identidades culturais/nacionais.

A questão das identidades está contida em uma série de pesquisas realizadas pelos teóricos adeptos dos Estudos Culturais. A disciplina, por assim dizer, constituise como uma vertente da Antropologia Cultural, tendo por abordagem uma empenhada defesa do discurso das minorias, das obras ditas "marginais". Tais estudos têm evoluído consideravelmente, desde o final do século $\mathrm{XX}$, principalmente sob o impacto do fenômeno da globalização, compreendido como uma integração das sociedades globais em um conjunto unificado, no qual não existem fronteiras para os intercâmbios culturais, gerando uma homogeneização cultural no globo. Stuart 
Hall (2004) explica que a globalização é um processo cujas raízes se concentram na modernidade; desde então, abriga os processos, atuantes numa escala global, que atravessam fronteiras nacionais, integrando e conectando comunidades e organizações em novas combinações de espaço-tempo, tornando o mundo, em realidade e em experiência, mais interconectado.

Perante a ação da globalização sobre a sociedade como um todo, está acontecendo uma reação contrária; segundo o antropólogo jamaicano e renomado culturalista Stuart Hall, "as identidades nacionais e outras identidades 'locais' ou particularistas estão sendo reforçadas [grifo do autor] pela resistência à globalização" (HALL, 2004, p. 69). A afirmativa confirma nossa hipótese: as produções "locais", geralmentemarginalizadas, em funçãodoscânones consolidados, revigoram-se neste momento histórico. $\mathrm{Na}$ mesma esteira, o vasto conjunto das obras ditas marginais está em pauta. Com os Estudos Culturais, podemos verificar a valorização das obras marginais, o que se constitui, em termos gerais, pela análise da identidade cultural, de forma a localizar e compreender as características peculiares de cada produção, contextualizada no tempo e no espaço. Tal valorização pode ser compreendida: segundo Hall, "ao lado da tendência em direção à homogeneização global, há também uma fascinação com a diferença e com a mercantilização da etnia e da 'alteridade'. Há, juntamente com o impacto do 'global', um novo interesse pelo 'local'” (HALL, 2004, p. 77).

Em síntese: da Modernidade, que valorizava o cânone, à atualidade, que valoriza as culturas locais, percebemos uma considerável mudança na concepção de valor das obras. Algumas manifestações artísticas e/ ou culturais tornam-se, inclusive, marcos de ruptura com a tradição, pela novidade e ousadia com que são concebidas, sendo valorizadas com base nos traços culturais que demonstram a identidade de grupos sociais. Nesse contexto, o que se apresenta como objeto de estudos da Literatura Comparada é o conjunto das literaturas marginais, um vastíssimo leque de opções de 
trabalhos realizados no mundo não canônico, como a América Latina, a Ásia, a África e a Oceania. Juntem-se a esse grupo os grupos de minorias, tais como as mulheres e os gays. A literatura pós-colonial é um dos grandes focos de atenção da Literatura Comparada, ante os Estudos Culturais, vindo a ser trabalhada em pesquisas acadêmicas e discutida em congressos de Literatura Comparada em todo o mundo - contrariando, por assim dizer, a tradição do cânone.

Uma forma de rever o que se encontra consolidado pela tradição seria a inversão dos valores, dos costumes, dos ritos e mitos já consolidados. Jorge Luís Borges (1970), quando questiona a noção de autoria, através de seu célebre ensaio "Pierre Menard, autor de Quixote", de certa forma comete uma afronta à tradição do cânone. Sabemos que o autor de Dom Quixote é Miguel de Cervantes um dos maiores, senão o maior cânone da literatura em língua espanhola. Borges reinventa o Quixote, através de Menard, um possível segundo autor, que rompe com a constituição original da obra de Cervantes. Mais que isso, subverte a ordem da tradição canônica, ironizando a glória do autor, a originalidade da obra, a cristalização de uma pessoa, na qualidade de autor (original).

Outra maneira de rever a tradição seria através da valorização de gêneros de obras considerados menores, em todo o decorrer da história da arte. Esse é o caso da arte cômica, basicamente o teatro cômico. Para analisar e demonstrar essa possível mudança, tomamos por base a teoria benjaminiana, da qual extraímos a noção de experiência, que se aplica às releituras de obras de arte. Vejamos o caso de duas peças teatrais cômicas, escritas por dois dramaturgos que vivenciaram a Modernidade: Oscar Wilde e Arthur Azevedo.

Visto que a obra desses dramaturgos é bastante vasta, entendemos que seria sensata a opção pela amostragem. Selecionamos duas peças, as quais se destacaram na época de sua produção, tendo criado polêmicas variadas no decorrer dos anos e chegado ao século XXI com considerável repercussão: The importance 
of being earnest, de Oscar Wilde, e $A$ capital federal, de Arthur Azevedo.

Com algumas adaptações, The importance of being earnest foi representada pelo "Grupo Tapa" no Rio de Janeiro, no início do ano de 2004, sob o título $A$ importância de ser fiel. Enquanto isso, $A$ capital federal também permaneceu nos palcos cariocas, tendo sido modificada em poucos aspectos ${ }^{5}$. Tais trabalhos, além de representar a identidade cultural de seus autores de forma evidente, são representados até os dias atuais, possibilitando a demonstração da teoria de Benjamin, particularmente da noção de experiência - noção que, para nós, é o fundamento da valorização do cômico na atualidade.

Existem inúmeras maneiras de rever a tradição e o incômodo entrelugar do cânone, na Pós-Modernidade. Seria impensável citar e exemplificar todas(!), mas podemos entender um ponto comum entre elas: o questionamento. Para toda e qualquer revisão e/ou releitura do cânone constituído através da tradição, existe um questionamento a orientar as discussões, com a sensatez de investigar objetos de valor cultural, cuja importância poderá ser considerada pelas futuras gerações.

\section{Considerações finais}

Apesar de nossa atenção dada às obras marginais, nossa proposta não se faz sobre o extremismo da destruição do cânone, mas de uma relativização do valor cultural das produções, de forma a criar uma nova atitude diante de produções que não tiveram o devido reconhecimento. Georg Otte (1999), ao analisar a questão do cânone em Walter Benjamin, esclarece que pode haver um equilíbrio entre o poder do culto e o da destruição:

Queremos deixar claro, porém, que existe um meio termo entre esses dois extremos, entre a destruição e o culto, e que há uma certa necessidade de questionar o culto existente. Pois, ao contrário da opinião defendida por Benjamin [...], não achamos que a solução da questão da aura - e
5 Um dos aspectos é a apoteose (na peça inaugural fez-se uma apoteose à vida rural; na peça adaptada fez-se uma apoteose à vida urbana, como homenagem à cidade do Rio de Janeiro). 
também do cânone - seja sua destruição, porém a conscientização de que ela é algo construído no passado que precisa ser reconstruído no presente (OTTE, 1999, p. 10).

Essa reconstrução proposta passa, por assim dizer, pela Desconstrução (a teoria-chave de Foucault e Derrida), "apropriada" pelos Estudos Culturais, que reavaliam as manifestações artísticas e/ou culturais, independentemente dos velhos critérios de consagração das obras. A Escola do Ressentimento - como Harold Bloom ironicamente denomina os teóricos culturalistas - passa a rever e a reconstruir os conceitos acerca das obras ditas "marginais", como é o caso da literatura póscolonial, da literatura feminina, gay, e da obra cômica.

Apesar de toda a evolução que as obras marginais já conquistaram, desde as últimas décadas do século $\mathrm{XX}$, há um amplo espaço a ser conquistado, principalmente neste momento de desconstruções e reconstruções de conceitos, ideias e métodos defendidos por meio de bases teóricas desenvolvidas pelos filósofos Michel Foucault e Jacques Derrida, "apropriadas" pelos Estudos Culturais. Nesse sentido, a tradição não se perde; ela se renova, através da retomada de obras que, acessíveis pela técnica, não ficam mais confinadas em um isolamento "museal"... Afinal, "é citando o cânone que destruímos sua aura" (OTTE, 1999, p.15). E é citando a tradição que renovamos a cultura - e a sociedade. 


\section{Referências}

BENJAMIN, Walter. Obras escolhidas I: magia e técnica, arte e política: ensaios sobre literatura e história da cultura. 6. ed. São Paulo: Brasiliense, 1993. 253 p.

BLOOM, Harold. O cânone ocidental: os livros e a escola do tempo. Rio de Janeiro: Objetiva, 2001.

BORGES, Jorge Luís. Pierre Menard, autor de Quixote. In:

Fiç̧ôes. Porto Alegre: Globo, 1970.

CANDIDO, Antônio. Literatura e sociedade: estudos de teoria e história literária. São Paulo: Nacional, 1975.

CARVALHAL, Tânia Franco. Literatura comparada. São Paulo: Ática, 1986.

COMPAGNON, Antoine. O demônio da teoria: literatura e senso comum. Belo Horizonte: Editora da UFMG, 2003.

CONNOR, Steven. Teoria e valor cultural. São Paulo: Loyola, 1994.

COUTINHO, Eduardo F; CARVALHAL, Tânia F. (Orgs.). Literatura comparada: textos fundadores. Rio de Janeiro: Rocco, 1994.

DERRIDA, Jacques. A escritura e a diferença. Trad. Maria Beatriz M. N. Silva. São Paulo: Perspectiva, 1971.

GEERTZ, Clifford. A interpretação das culturas. Rio de Janeiro: LTC, 1989.

HALL, Stuart. Da diáspora: identidades e mediações culturais. Trad. Adelaine La Guardia Resende et al. Belo Horizonte: Ed. da UFMG; Brasília: Unesco, 2003.

HALL, Stuart. A identidade cultural na pós-modernidade. Trad. Tomaz T. Silva, Guacira L. Louro. Rio de Janeiro: DP\&A, 1998. 
JOHNSON, Richard; ESCOSTEGUY, Ana Carolina; SCHULMAN, Norma. Org. e trad. Tomaz T. Silva. O que é, afinal, Estudos Culturais? Belo Horizonte: Autêntica, 2000.

KOTHE, Flávio R. (Org.). Walter Benjamin. São Paulo: Ática, 1985.

MARQUES, Reinaldo e VILELA, Lúcia H. (Orgs.). Valores: arte, mercado, política. Belo Horizonte: Editora da UFMG; Abralic, 2002.

MARQUES, Reinaldo; BITTENCOURT, Gilda Neves (Orgs.). Limiares críticos: ensaios sobre Literatura Comparada. Belo Horizonte: Autêntica, 1998.

NASCIMENTO, Evando. Derrida e a literatura. Niterói: Ed. UFF, 1999.

NASCIMENTO, Evando; GLENADEL, Paula (Org.). Em torno de Derrida. Rio de Janeiro: 7 Letras; Niterói: Ed. UFF, 2001.

OTTE, Georg. A obra de arte e a narrativa: reflexões em torno do cânone em Walter Benjamin. In: OTTE, Georg; OLIVEIRA, Silvana Pessôa de (Orgs.). Mosaico crítico: ensaios sobre literatura contemporânea. Belo Horizonte: Autêntica; Núcleo de Estudos Latino-Americanos (Nelam-Fale/UFMG), 1999, p. 9-15.

OTTE, Georg. Linha, choque e mônada: tempo e espaço na obra tardia de Walter Benjamin. Tese de doutorado. Belo Horizonte: UFMG, 1994.

PEREIRA, Maria Antonieta. REIS, Eliana Lourenço de L. (Org.). Literatura e Estudos Culturais. Belo Horizonte: Faculdade de Letras da UFMG, 2000.

PERRONE-MOISÉS, Leyla. Altas literaturas: escolha e valor na obra crítica de escritores modernos. São Paulo: Companhia das Letras, 1998.

PERRONE-MOISÉS, Leyla. Inútil poesia. São Paulo: Companhia das Letras, 2000. 
REIS, Eliana L. de L. Descentrando a crítica: a literatura das minorias. Revista de Estudos Germânicos, V.9, n.1, p.22-29, dez. 1988.

SANTIAGO, Silviano. Uma literatura nos trópicos: ensaios sobre dependência cultural. Rio de Janeiro: Rocco, 2000.

SANTIAGO, Silviano. O cosmopolitismo do pobre. Belo Horizonte: Editora da UFMG, 2005.

SOUZA, Eneida Maria de. Literatura Comparada: o espaço nômade do saber. Revista Brasileira de Literatura Comparada. São Paulo, n 2, p.19-24, maio, 1994.

SOUZA, Eneida Maria de. Os livros de cabeceira da crítica. In: ANTELO, Raul et al(Org.). Declínio da arte: ascensão da cultura. Florianópolis: Abralic, 1998.

SOUZA, Eneida Maria de. A teoria em crise. In: SOUZA, Eneida Maria de. Crítica cult. Belo Horizonte: Editora da UFMG, 2002.

WILLIAMS, Raymond. Cultura. São Paulo: Paz e Terra, 1992.

YUDICE, George. Conveniência da cultura: usos da cultura na era global. Trad. Marie Anne Kramer. Belo Horizonte: Editora da UFMG, 2004.

FONTES DOCUMENTAIS. Acervo de textos do GPEFE - Grupo de Pesquisas em Escola de Frankfurt e Educação (UEMG-Barbacena). 
